\title{
ANALYSIS OF DEGREES OF REGIONAL ORIGINAL INCOME DECENTRALIZATION AND INDEPENDENCE AND THE RELATIONSHIP WITH REGIONAL EXPENDITURE PRODUCTIVITY IN MAGELANG REGENCY 2016-2020
}

\author{
Arma Riski Nur Cahyani ${ }^{1}$, Nuwun Priyono ${ }^{2}$ \\ 1,2 \\ Akuntansi, Ekonomi, Universitas Tidar \\ E-mail: ${ }^{1)}$ armariski@gmail.com, ${ }^{2)}$ nuwunpriyono@untidar.ac.id
}

\begin{abstract}
This research aims to (1) examine the level of fiscal decentralization degrees in Magelang Regency, (2) examine the level of financial independence in Magelang Regency, (3) examine the level of regional expenditure productivity of Magelang Regency, (4) examine the relationship of decentralization degrees and independence of fiscal with regional expenditure productivity in Magelang Regency. This research uses secondary data in the form of time series from 2016-2020 consisting of the realization of Magelang Regency APBD (Regional Revenue and Expenditure Budget), the realization of Magelang Regency PDRB (Local Gross Domestic Product (GDP)). In analyzing this study using the analysis of the Degree of Fiscal Decentralization (DDF), the analysis of the Degree of Fiscal Independence (DKF), the analysis of Regional Expenditure Productivity $(P B D)$, and the Pearson Correlation analysis. The results showed that DDF value of 10,62, DKF value of 12,18, and PBD of 18,38, all three calculations were in low category. Therefore, the findings shows that there is a negative relationship that is relatively strong and real.
\end{abstract}

Keywords: Decentralization, Independence, Regional Expenditure

\section{INTRODUCTION}

Regional development serves as a measure for achieving national development. This allows the government to run its own household in accordance with relevant law number 12 of 2008, which specifies that the government would operate under the decentralization principle. Local governments have sought to maximize regional potential since the introduction of regional autonomy in order to fulfill the goals of regional autonomy, namely regional independence. Regional governments with regional independence can freely manage and maximize regional resources, allowing them to take the lead in generating regional revenue. Yet it is recognized that when a region's Regional Original Income rises, the Regional Government's reliance on the Central Government in its Regional Revenue and Expenditure Budget (hereinafter referred to as APBD) declines. This becomes a process of continuous change toward progress in the economic field by includes realizing community welfare in order to assist and improve economic development. Furthermore, economic development become of greater concern in the regional context because it can encourage the positive achievement of goals through the process of managing existing resources and forming a partnership between local governments and the private sector to create new jobs, as well as stimulate the development of economic activities in the region. 
Since the implementation of fiscal decentralization, the realization of regional income has increased in Magelang Regency. The realization of regional original income has climbed over the 2016-2020 period, despite a decline in 2018, but this can be addressed in 2020 by growing regional income, as well as the realization of total spending, which has increased and decreased.

With the fluctuating rate of economic growth between regions, fluctuations in the implementation of fiscal decentralization are also followed, but the variation remains focused on accelerating economic growth and development. The research objectives can be formulated: 1) examine the degree of fiscal decentralization in Magelang Regency, (2) examine the degree of fiscal independence in Magelang Regency, (3) examine the productivity level of regional expenditure in Magelang Regency, (4) examine the relationship between the degree of decentralization and fiscal independence with productivity of. regional expenditure in Magelang Regency.

\section{LITERATURE REVIEW}

\subsection{Fiscal Decentralization}

According to Syaukani et al. (2003) decentralization is a mechanism in the implementation of the delegation of authority from the central government to local governments and the community in carrying out the improvement of the welfare of the community. Fiscal decentralization is a mandate with accountability and power sharing and authority for decision-making in the fiscal sector, including aspects of revenue (tax assignment) and aspects of expenditure (expenditure assignment). In broad sense, fiscal decentralization refers to the delegation of budgetary responsibility from a higher level of government to a lower level of government in order to support government functions and public services.

Table 1 Regional Fiscal Decentralization Degree Interval Scale

\begin{tabular}{cc}
\hline Interval (\%) & The Level of Regional Ability \\
\hline $0,00-12,50$ & Very Low \\
$12,51-25,00$ & Low \\
$25,51-37,50$ & Medium \\
$37,51-\geq 50,00$ & High/Good \\
\hline
\end{tabular}

\subsection{Regional Financial Independence Ratio}

Halim (2002) indicates a measure of the strength of local governments to pay taxes and levies on regional development activities and services as a source of regional income can be formulated as:

$$
\text { Ratio of KKD (Regional Financial Independence })=\frac{\text { Original Local Government Revenue }}{\text { Central or Provincial Government Assistance and Loans }}
$$

Based on the formula above, it shows the extent to which the region is implicated in the field of external funding. The more abundant the ratio means the lower the area depends on subsidies from outside the government and vice versa. The existence of this scale also symbolizes the level of people's contribution in advancing the region. The larger the scale, 


\section{JOURNAL OF MANAGEMENT, ACCOUNTING, GENERAL FINANCE AND INTERNATIONAL ECONOMIC ISSUES (MARGINAL) \\ VOLUME 1 ISSUE 2 (2022)}

the greater the contribution of the people in paying regional taxes and levies which are elements of PAD (Original Local Government Revenue).

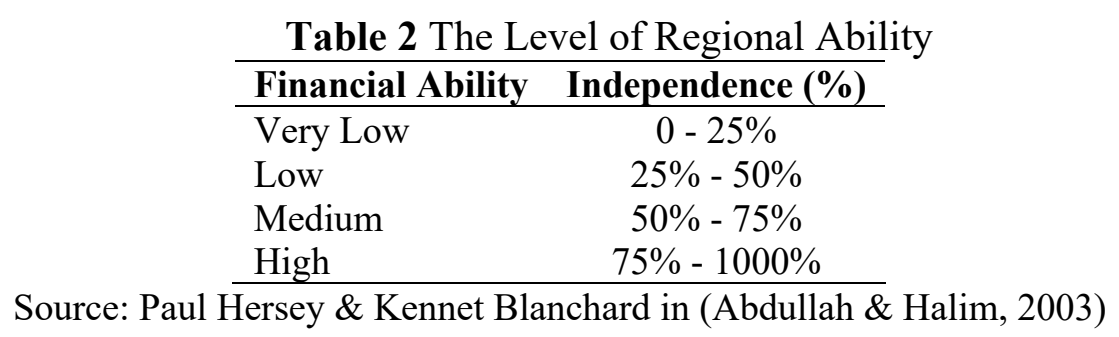

\subsection{Regional Original Income}

According to Hanif (2007) Regional Original Income is regional income that comes from various sources of revenue owned by the region such as regional tax revenues, regional levies, the results of separated regional wealth management and other legitimate regional original income, this is and is called regional assets. Therefore, local governments are given the freedom to explore the source of income in the region, but it must be in line with regional autonomy and the prevailing principles of decentralization.

Furthermore, according to Sirozujilam and Mahalli (2011) Sources of Local Original Income include:

a. Local tax

Regional Tax is a withdrawal made by the government against an individual with all tax objects, movable or immovable objects. This tax is used for general expenditures whose remuneration is not directly given, while its implementation can be directly imposed.

b. Regional Retribution

Regional levies are regional levies as financing for services or facilities for private persons which are carried out by the regional government directly and in fact.

c. Results of separated Regional Wealth Management

The results of this management that are separated are regional income derived from separated wealth management, including dividend income, sales of regionally owned shares.

d. Other Legitimate Regional Original Income

Other legitimate Regional Original Income (PAD) is revenue derived from the sale of fixed assets and current accounts.

\subsection{Regional Revenue and Expenditure Budget (APBD)}

Based on Mamesah (1995) and Halim (2007) APBD is a government monetary operational plan which describes elimination assumptions in order to handle activities and projects in the region in one fiscal year, besides that it also shows the estimated revenue and various fields of regional revenue that useful for walling existing financing.

\subsection{Budget of Revenue}

Statement of Financial Accounting Standards (PSAK) No. 23 Income is income from economic utilization derived from activities during a period. Meanwhile, regional income is all income that is the right of the region. Moreover, (Mardiasmo, 2004) explain that budget is an estimate of the performance to be achieved during a certain period expressed in 
financial measures, while the regional budget is a right in the form of finance which becomes the wealth of the region as a financial measure. Regional income consists of all cash receipts through the regional general treasury account, which can add equity to current funds, which are regional rights in the current fiscal year and do not need to be repaid by the region.

\subsection{Budget of Expenditure}

The expenditure is used in the public sector, not in the business sector. Hence, spending in the public sector is related to budgeting, namely by showing the financial amount that has been issued during one budget year. The expenditure budget is an amount of expenditure used for regional expenditures in a certain fiscal year which is the burden of the region.

According to Law Number 32 of 2004 concerning Regional Government, the form of APBD consists of:

1. Regional Income, namely all regional authority income which is legalized as an addition to the value of net income related to one fiscal year. Regional income includes, pure regional wealth, Proportion Budget, and other legal regional income.

2. Regional Expenditure is a regional authority that is ratified for the reduction of the value of net income within the period of the relevant fiscal year. Regional expenditure, which includes personnel costs, goods duties, interest, subsidies, donations, social subsidies, capital costs, profit sharing fees and monetary subsidies, as well as immeasurable fees.

3. Financing is a financing facility provided to an area in the form of an output that must be repaid or an estimate that will be re-inputted, according to the linked estimate year and the estimated years to come. Reserves from the marketing of regional assets set aside, loan inputs, re-input on loan subsidies. The output of wealth froze the creation of stock money, the involvement of regional government funds, including non-profit funding of regional governments, as well as management donations, namely the Remaining Payment of the Budget for the previous fiscal year, dissolving of loans.

\section{RESEARCH METHOD}

This study uses secondary data types based on the 2016-2020 time series. The data source in the form of the realization of the Revenue and Expenditure Budget (APBD) and Local Gross Domestic Product (GRDP) comes from the Central Statistics Agency (BPS) of Magelang Regency. Therefore, the analysis data can be formulated in the following formula.

The formula for the degree of fiscal decentralization:

$$
\mathrm{DDt}=\frac{\mathrm{PADt}}{\mathrm{TPDt}} X 100 \%
$$

Notes :

Value of Degree of Fiscal Decentralization in ' $t$ ' period (DDt )

Realized value of PAD in ' $t$ ' period (PADt )

Realized value of total regional revenue in ' $t$ ' period (TPDt ) 


\section{JOURNAL OF MANAGEMENT, ACCOUNTING, GENERAL \\ FINANCE AND INTERNATIONAL ECONOMIC ISSUES \\ (MARGINAL) \\ VOLUME 1 ISSUE 2 (2022)}

The formula for the degree of fiscal independence:

Notes :

$$
\mathrm{DKFt}=\frac{\mathrm{PADt}}{\text { Transfer } \mathrm{t}+\text { Loan } \mathrm{t}} X 100 \%=\frac{\text { PADt }}{\text { TPDt }} X 100 \%
$$

The value of the degree of fiscal independence in ' $t$ ' period (DKFt)

Realized value of PAD in ' $t$ ' period (PADt )

Realization value of balancing fund period ' $t$ ' (TDPt )

Regional expenditure productivity formula:

Notes :

$$
\text { PBDt }=\frac{\text { PBDt }}{\text { PDRBt }} X 100 \%
$$

The value of regional expenditure productivity to GRDP in ' $t$ ' period (GDP)

Realized value of total regional expenditure in ' $t$ ' period (TBDt)

Value of gross regional domestic product in ' $t$ ' period (GDPt)

Furthermore, the formula used to analyze the relationship between the degree of decentralization and fiscal independence with the productivity of regional expenditures is used by the Pearson correlation analysis tool (Dajan, 1995):

$$
r=\frac{\mathrm{n} \sum \mathrm{xy}-\left(\sum \mathrm{x}\right)\left(\sum \mathrm{y}\right)}{\sqrt{\left(n \sum x^{2}-\left(\sum \mathrm{x}\right)^{2}\right)\left(n \sum y^{2}-\left(\sum y\right)^{2}\right)}}
$$

Notes :

$\mathrm{n}=$ Number of pairs of data $\mathrm{X}$ (degree of fiscal decentralization and fiscal independence) and data $\mathrm{Y}$ (Productivity of regional expenditure)

$\Sigma \mathrm{x}=$ Total Amount of Variable $\mathrm{X}$ (Degree of fiscal decentralization and fiscal independence)

$\Sigma y=$ Total of Variable Y (Productivity of regional expenditure)

$\Sigma \mathrm{x}^{2}=$ Square of Total Number of Variables X (Degree of fiscal decentralization and fiscal independence)

$\Sigma y^{2}=$ Square of Total Number of Variable Y (Productivity of regional expenditure)

$\Sigma x y=$ Product of the Total Number of Variables X (Degree of fiscal decentralization and fiscal independence) and Variable Y (Productivity of regional expenditures)

\section{RESULT AND DISCUSSION}

4.1. Research Result

4.1.1. Calculation of the Degree of Decentralization and Independence of Original Regional Revenue and Its Relationship with Regional Expenditure Productivity of Magelang Regency in 2016-2020.

Table 3 Ratio of fiscal decentralization of Magelang Regency 2016-2020 


\begin{tabular}{cccccc}
\hline Period & PAD & TPD & $\begin{array}{c}\text { DDF }= \\
\text { (PAD/TPD) }\end{array}$ & Ratio & Position \\
\hline 2016 & 288.485 .678 .128 & 2.036 .310 .089 .428 & 14,17 & Low & Weak \\
2017 & 403.561 .238 .310 & 2.271 .336 .015 .858 & $\mathbf{1 7 , 7 7}$ & Low & Weak \\
2018 & 325.089 .093 .092 & 2.302 .190 .543 .616 & 14,12 & Low & Weak \\
2019 & 417.178 .099 .961 & 2.575 .439 .825 .755 & 16,20 & Low & Weak \\
2020 & 329.763 .484 .748 & 2.379 .563 .351 .028 & 13,86 & Low & Weak \\
\hline Average & $\mathbf{3 5 2 . 8 1 5 . 5 1 8 . 8 4 8}$ & $\mathbf{2 . 3 1 2 . 9 6 7 . 9 6 5 . 1 3 7}$ & $\mathbf{1 5 , 2 2}$ & Low & Weak \\
\hline \multicolumn{7}{c}{ Source: Central Agency of Statistics of Magelang Regency (data processed) }
\end{tabular}

Based on the calculation of table above, it can be seen that the ratio of fiscal decentralization in 2016-2020 is 15,22, which is classified as a low and weak ratio scale.

Table 4 Ratio of Degrees of Fiscal Independence in Magelang Regency 2016-2020

\begin{tabular}{cccccc}
\hline Period & PAD & DP & $\begin{array}{c}\text { DKF }= \\
\text { (PAD/DP) }\end{array}$ & Ratio & Position \\
\hline 2016 & 288.485 .678 .128 & 1.362 .306 .913 .419 & 21,18 & Low & Weak \\
2017 & 403.561 .238 .310 & 1.407 .243 .138 .226 & 28,68 & Currently & Currently \\
2018 & 325.089 .093 .092 & 1.398 .132 .841 .570 & 23,25 & Low & Weak \\
2019 & 417.178 .099 .961 & 1.452 .804 .059 .102 & 28,72 & Currently & Currently \\
2020 & 329.763 .484 .748 & 1.390 .679 .533 .778 & 23,71 & Low & Weak \\
\hline Average & $\mathbf{3 5 2 . 8 1 5 . 5 1 8 . 8 4 8}$ & $\mathbf{1 . 4 0 2 . 2 3 3 . 2 9 7 . 2 1 9}$ & $\mathbf{2 5 , 1 1}$ & Low & Weak \\
\hline \multicolumn{7}{c}{ Source: Central Agency of Statistics of Magelang Regency (data processed) }
\end{tabular}

Based on the table calculation, the degree of fiscal independence in 2016-2020 is 25,11 which is classified as a low-scale and weak ratio.

Table 5 Regional Expenditure Productivity Ratio in Magelang Regency 2016-2020

\begin{tabular}{cccccc}
\hline Period & TBD & GDP & $\begin{array}{c}\text { GDP= } \\
\text { (TBD/GRDP) }\end{array}$ & Ratio & Position \\
\hline 2016 & 2.073 .797 .409 .332 & 19.882 .240 .000 .000 & 10,43 & Low & Weak \\
2017 & 2.451 .441 .154 .742 & 20.974 .800 .000 .000 & 11,69 & Low & Weak \\
2018 & 2.486 .540 .561 .169 & 22.082 .800 .000 .000 & 11,26 & Low & Weak \\
2019 & 2.568 .593 .603 .007 & 23.253 .150 .000 .000 & 11,05 & Low & Weak \\
2020 & 2.303 .487 .296 .061 & 22.861 .470 .000 .000 & 10,08 & Low & Weak \\
\hline Average & $\mathbf{1 . 4 7 1 . 7 2 4 . 2 9 2 . 0 4 7}$ & $\mathbf{2 1 . 8 1 0 . 8 9 2 . 0 0 0 . 0 0 0}$ & $\mathbf{1 0 , 9 0}$ & Low & Weak \\
\hline \multicolumn{6}{c}{ Source: Central Agency of Statistics of Magelang Regency (data processed) }
\end{tabular}

Based on the calculations in table 3 , the ratio of regional expenditure productivity in 2016-2020 is 10,90, which is classified as a low-scale and weak ratio.

\subsubsection{The Relationship between the Degree of Decentralization and Fiscal Independence on Regional Expenditure Productivity in Magelang Regency}

Table 6 The degree of decentralization on the productivity of regional decentralization expenditures 


\section{JOURNAL OF MANAGEMENT, ACCOUNTING, GENERAL FINANCE AND INTERNATIONAL ECONOMIC ISSUES \\ (MARGINAL) \\ VOLUME 1 ISSUE 2 (2022)}

\begin{tabular}{|c|c|c|c|c|c|c|}
\hline No & Period & $\mathbf{X}$ & $\mathbf{y}$ & $\mathbf{x}^{\wedge^{\mathbf{2}}}$ & $\mathbf{y}^{\wedge^{\mathbf{2}}}$ & $\mathbf{x y}$ \\
\hline 1 & 2016 & 14,17 & 10,43 & 200,7889 & 108,7849 & 147,7931 \\
\hline 2 & 2017 & 17,77 & 11,69 & 315,7729 & 136,6561 & 207,7313 \\
\hline 3 & 2018 & 14,12 & 11,26 & 199,3744 & 126,7876 & 158,9912 \\
\hline 4 & 2019 & 16,2 & 11,05 & 262,44 & 122,1025 & 179,01 \\
\hline 5 & 2020 & 13,86 & 11,08 & 192,0996 & 122,7664 & 153,5688 \\
\hline \multicolumn{2}{|c|}{ Total } & 76.12 & 76,12 & 55,51 & 1170,476 & 617,0975 \\
\hline
\end{tabular}

$r=\frac{\mathrm{n} \sum \mathrm{xy}-\left(\sum \mathrm{x}\right)-\left(\sum \mathrm{y}\right)}{\sqrt{\left(n \sum x^{2}-\left(\sum \mathrm{x}\right)^{2}\right)\left(n \sum y^{2}-\left(\sum y\right)^{2}\right)}}$

$r=0,766$

$t=\frac{\mathrm{r} \sqrt{n-2}}{\sqrt{1-r^{2}}}$

$t=0,131$

From these calculations, it can be concluded that the degree of decentralization in the calculation of the Pearson correlation to regional expenditure is 0,766 , so it can be said to be strongly and significantly related.

Table 7 The degree of independence on the productivity of regional decentralization expenditures

\begin{tabular}{|c|c|c|c|c|c|c|}
\hline No & Period & $\mathbf{x}$ & $\mathbf{y}$ & $\mathbf{x}^{\mathbf{2}}$ & $\mathbf{y}^{\mathbf{2}}$ & $\mathbf{x y}$ \\
\hline 1 & 2016 & 21,18 & 10,43 & 448,5924 & 108,7849 & 220,9074 \\
\hline 2 & 2017 & 28,68 & 11,69 & 822,5424 & 136,6561 & 335,2692 \\
\hline 3 & 2018 & 23,25 & 11,26 & 540,5625 & 126,7876 & 261,795 \\
\hline 4 & 2019 & 28,72 & 11,05 & 824,8384 & 122,1025 & 317,356 \\
\hline 5 & 2020 & 23,71 & 11,08 & 562,1641 & 122,7664 & 262,7068 \\
\hline \multicolumn{2}{|c|}{ Total } & 125.54 & 125,54 & 55,51 & 3198,7 & 617,0975 \\
\hline
\end{tabular}

$r=\frac{\mathrm{n} \sum \mathrm{xy}-\left(\sum \mathrm{x}\right)-\left(\sum \mathrm{y}\right)}{\left.\sqrt{\left(n \sum x^{2}-\left(\sum \mathrm{x}\right)^{2}\right)(} n \sum y^{2}-\left(\sum y\right)^{2}\right)}$

$r=0,645$

$t=\frac{\mathrm{r} \sqrt{n-2}}{\sqrt{1-r^{2}}}$

$t=0,240$

From these calculations, it can be concluded that the degree of decentralization in the calculation of the Pearson correlation to regional spending is 0,645 , so it can be said to be strongly and significantly related.

\subsection{Discussion}

4.2.1. Analysis of the degree of fiscal decentralization in Magelang Regency 
The degree of fiscal decentralization is a barometer of the ability of local governments in their finances to finance their regional expenditures, based on this it can be seen that the amount of financial collection ability originating from the region itself can be seen. Hence, this measure is expressed as the degree of fiscal decentralization ratio.

Based on table 3, it can be seen that during the period 2016-2020 PAD and TPD fluctuated. As a result, from the calculation of the ratio of the degree of fiscal decentralization in Magelang Regency with an average of 15,22, so that it can be categorized as low and in the category of a weak position.

\subsubsection{Degree of Fiscal Independence in Magelang Regency}

To find out the degree of fiscal independence in Magelang Regency, it is done by comparing the realized value of regional original income (PAD) to the balancing fund (DP). Based on table 4, it can be seen that during the period 2016-2020 PAD and DP fluctuated. As a result, from the calculation of the ratio of the degree of fiscal independence in Magelang Regency with an average of 25,11 , so that it can be categorized as low and in the category of weak position.

\subsubsection{Productivity Analysis of Regional Expenditures in Magelang Regency}

To find out the productivity of regional expenditures in Magelang Regency, it is done by comparing the total regional expenditures to the GRDP. Based on table 5, it can be seen that during the period 2016-2020 TBD and GRDP fluctuated. Then from the calculation of the degree of productivity expenditure ratio in Magelang Regency with an average of 10,90, so that it can be categorized as low and in the category of weak position.

\subsubsection{The Relationship between the Degree of Decentralization and Fiscal Independence on Regional Expenditure Productivity in Magelang Regency}

Based on the calculation above, it can be seen the relationship between the degree of decentralization and fiscal independence on the productivity of regional expenditures in Magelang Regency using the Pearson correlation formula. With this formula, it can be seen whether there is a relationship or relationship between the variables being measured.

From the calculation of the Pearson correlation (r) between the variables of the degree of decentralization on the productivity of regional expenditures with a value of 0,766 , it shows that the relationship/correlation between the degrees of decentralization and the productivity of regional expenditures has a strong and significant correlation/correlation, with a positive relationship pattern. Negative means that it shows a unidirectional relationship in the sense that there is an increase in the degree of decentralization at the same time that there is an increase in the productivity of regional spending and vice versa.

Pearson correlation/value ( $r$ ) between the variable of fiscal independence on the productivity of regional spending is 0,645 . Shows that the relationship/correlation between fiscal independence and productivity of regional expenditures has a strong and real relationship/correlation, with a positive relationship. Negative means showing a unidirectional relationship in the sense of increasing fiscal independence at the same time there is also an increase in regional expenditure productivity and vice versa. 


\section{JOURNAL OF MANAGEMENT, ACCOUNTING, GENERAL FINANCE AND INTERNATIONAL ECONOMIC ISSUES \\ (MARGINAL) \\ VOLUME 1 ISSUE 2 (2022)}

\section{CONCLUSION}

1. Based on the average degree of fiscal decentralization in the Magelang Regency in $2016-2020$ of $15,22 \%$ which is categorized as low, while the average ratio of the Degree of Fiscal Independence of $25,11 \%$ is categorized as low and for the average Regional Expenditure Productivity ratio of $10,90 \%$ which is categorized as low.

2. The results of the analysis calculation concluded that there is a relationship between the degree of decentralization and fiscal independence with regional expenditure productivity in Magelang Regency for the 2016-2020 period, has a strong and real relationship/correlation, with a negative relationship pattern. Negative means that it shows an opposite relationship in terms of an increase in the degree of decentralization and fiscal independence at the same time there is an increase in the productivity of regional expenditure and vice versa.

\section{Suggestion}

1. The Magelang Regency Government is expected to be more optimal in optimizing PAD collected from the regional tax and levy sector and more seriously in supervising regional financial management with orderly administration and increasing cooperation with related parties.

2. The Magelang Regency Government is also expected to conduct an audit of the implementation of regional financial management and the implementation of program activities to promote transparency and accountability.

\section{REFERENCES}

Abdullah, S., \& Halim, A. (2003). Pengaruh dana alokasi umum (DAU) dan pendapatan asli daerah (PAD) terhadap belanja pemerintah daerah: Studi kasus kabupaten/kota di Jawa dan Bali. Proceeding Simposium Nasional Akuntansi VI, 16-17.

Halim. (2002). Sumber Pendaptan Daerah.

Halim, A. (2007). Akuntansi Keuangan Daerah, Salemba Empat. Yogyakarta.

Hanif, N. (2007). Teori dan Praktik Pemerintahan dan Otonomi Daerah, Grasindo. Jakarta.

Mamesah, D. J. (1995). Sistem Administrasi Keuangan Daerah, Jakarta: PT. Gramedia Pustaka Utama.

Mardiasmo. (2004). Akuntansi Sektor Publik. Andi.

Sirojuzilam, \& Mahalli, K. (2011). Regional: Pembangunan, Perencanaan, dan Ekonomi. USU Press.

Syaukani, H. R., Gaffar, A., \& Rasyid, M. R. (2003). Otonomi Daerah Dalam Negara Kesatuan, cetakan 3. Pustaka Pelajar, Yogyakarta. 